\title{
Implementasi Pembelajaran Kooperatif Think Pair Share Guna Meningkatkan Kualitas Pembelajaran Sosiologi
}

\author{
Hamsah \\ Ilmu Administrasi Negara, Universitas Azzahra, hamsah@azzahra.ac.id
}

\begin{abstract}
Abstrak
Classroom action research merupakan penelitian yang terdiri dari 2 siklus dan 4 tahapan (perencanaan, tindakan, observasi dan refleksi). Setiap siklus dilaksanakan sebanyak 4 kali pertemuan di kelas X IPS, SMA Negeri I Lappariaja Kabupaten Bone dengan jumlah siswa 39 orang, 19 laki laki dan 20 perempuan. Penelitian ini bertujuan untuk meningkatkan hasil belajar sosiologi pokok bahasan nilai dan norma sosial dengan implementasi model pembelajaran kooperatif think pair share. Hasil analisis kuantitatif menunjukkan bahwa : (1) Hasil belajar siswa pada siklus I berada pada kategori sedang dengan skor rata-rata 65 dari skor ideal 100 dengan standar deviasi 10 dari jumlah siswa yang tuntas belajar sebanyak 13 dan mencapai persentase ketuntasan 33,3 \%. (2) Hasil belajar siswa pada siklus II berada pada kategori tinggi dengan skor rata-rata 79 dari skor ideal 100 dengan standar deviasi 9 dan jumlah siswa yang tuntas belajar sebanyak 37 dan mencapai persentase ketuntasan 94,9\%. Hasil analisis kualitatif menggambarkan terjadinya perubahan pada sikap siswa, tingkat kahadiran, keaktifan dan minat siswa selama proses pembelajaran.
\end{abstract}

Kata kunci: nilai, norma sosial, think pair share

\begin{abstract}
Classroom antion research is a study consisting of 2 cycles and 4 stages (planning, action, observation and reflection). Each cycle held 4 meeting in class X IPS, SMA Negeri I Lappariaja Bone Regency with 39 students, 19 boys and 20 girls. This study aims to improve the sociology learning outcomes of the subject of social values and norms by implementing think pair share cooperative learning model. The results of the quantitative analysis show that: (1) The learning outcomes of students in the first cycle are in the medium category with an average score of 65 from the ideal score of 100 with a standard deviation of 10 from the total number of students who complete learning as much as 13 and reach a percentage of $33.3 \%$ completeness. (2) Student learning outcomes in cycle II are in the high category with an average score of 79 of the ideal score of 100 with a standard deviation of 9 and the number of students who complete learning is 37 and reaches a percentage of $94.9 \%$ completeness. The results of the qualitative analysis describe changes in student attitudes, attendance levels, student activeness and interest during the learning process.
\end{abstract}

Keywords: values, social norms, think pair share

\section{PENDAHULUAN}

Pendidikan diharapkan mampu mendukung pembangunan di masa mendatang melalui pembelajaran yang dapat mengembangkan potensi siswa. Sehingga siswa pada akhirnya mampu untuk mengatasi problematika kehidupan yang dihadapinya. Oleh karena itu, transformasi ilmu pengetahuan haruslah mengandalkan metode pembelajaran yang tepat sasaran.

Oemar Hamalik (2003:38) menjelaskan tentang pembelajaran yang baik haruslah terdiri dari perpaduan unsur manusiawi, material, fasilitas, dan prosedur yang saling melengkapi. 
Hal tersebut berarti pembelajaran tidak selamanya harus berorientasi pada penguasaan materi tetapi bagaimana siswa dapat dilatih untuk berbagi satu sama lain. Pembelajaran yang dilakukan di kelas mesti dapat menyentuh segala potensi siswa (potensi nurani dan kompetensi).

Pentingnya kualitas pembelajaran mulai terasa jika seseorang telah memasuki kehidupan nyata di masyarakat khusunya dunia kerja. Apa yang dipelajari di sekolah mestilah mampu diterapkan dalam menghadapi permasalahan sehari-hari. Sementara tidak menutup kemungkinan apa yang dihadapi di kehudupan nyata tidak pernah dipelajari di sekolah.

Sejalan dengan apa yang disampaikan di atas, pembelajaran sosiologi sedikit banyaknya akan memberikan solusi dari serentetan permasalahan yang ada. Sosiologi sebagai ilmu sosial yang objek kajiannya berkaitan lansung dengan masyarakat termasuk masalah pendidikan.

Nilai dan norma sosial adalah salah satu pokok bahasan dalam sosiologi yang dirasa sangat penting untuk dipahami bersama. Sebagaimana dengan kita sebagai makhluk individu yang bermasyarakat masing-masing memiliki nilai dan norma yang dianggap penting. Nilai sebagai suatu yang dianggap berharga dan dijadikan dasar dan penentu dalam berperilaku (Daroeso:1986:20).

Nilai dan norma sosial menjadi salah satu fokus utama kajian sosiologi yang penting untuk diajarkan pada siswa di sekolah. Nilai sebagai konsepsi abstrak mengenai sesuatu yang baik dan buruk oleh masyarakat. Sedangkan norma adalah nilai yang dinormakan, sehingga nilai tersebut memiliki unsur sanksi jika dilanggar oleh masyarakat. Sejalan dengan itu, maka nilai dan norma menjadi penting ditanamkan pada siswa melalui pembelajaran di kelas.

Namun yang dihadapi hari ini, pencapaian tujuan pendidikan tidak semudah yang difikirkan. Hal ini dikarenakan terlalu banyaknya kendala teknis yang dihadapi, mulai dari lingkungan sekolah, tenaga pengajar, media dan metode pembelajaran dan terkhusus pada siswa itu sendiri.

Miarso (2004:45) mengungkapkan bahwa pembelajaran sebagai kegiatan yang disengaja dan memiliki tujuan agar terjadi perubahan yang menetap pada orang lain setelah melalaui pembelajaran. Kemudian menurut Kemp dalam Rusmono (2012:6) menyatakan bahwa pembelajaran sebagai proses yang utuh, memiliki fungsi dan bagian yang saling berhubungan untuk mewujudkan keberhasilan dalam belajar.

Masalah baru pun terjadi, dimana siswa kurang bersemangat dalam mengikuti pembelajaran terutama dalam belajar sosiologi. Siswa kebanyakan berdiam diri pada saat pembelajaran berlansung sehingga tidak ada gagasan baru yang muncul dari siswa, siswa semata menjadi pendengar dan pembelajaran pun hanya berpusat pada guru.

Dalam hal ini masalah yang terjadi adalah peserta didik yang kurang antusias dalam proses pembelajaran terutama dalam belajar sosiologi, siswa cendrung berdiam diri dan menjadi pendengar pada saat pembelajaran berlansung sehingga tidak ada gagasan baru yang terlahir dari peserta didik karena pembelajaran hanya berpusat pada guru.

Salah satu yang menyebabkan demikian adalah tidak digunakannya model pembelajaran yang bisa memberikan penekanan supaya siswa lebih aktif dan tidak berdiam diri dalam proses pembelajaran.

Permsalahan tersebut dapat diatasi dengan cara disamping guru menguasai materi, juga harus menggunakan model pembelajaran yang lebih inovatif, kreatif dan disukai siswa karena dianggap menyenangkan dalam proses pembelajaran.

Membangun kerjasama dalam pembelajaran menjadi penting bagi guru dan siswa. Dengan adanya kerjasama, akan membuat seseorang mampu melakukan lebih banyak dibandingkan bekerja dengan sendiri. Beberapa 
penelitian menyebutkan bahwa efisiensi dan efektivitas dapat tercapai melalui kegiatan kerjasama dalam kelompok (West, 2002:1).

Pembelajaran koperatif adalah model yang menekankan siswa untuk bisa saling bekerjasama dalam pembelajaran. Dimana setiap pembelajaran yang dilakukan, siswa senantiasa dibagi dalam kelompok besar maupun kecil untuk mencapai tujuan pembelajaran. Hal tersebut sejalan dengan pendapat Kindsyatter dalam Suparno (2007:134) bahwa peningkatan bidang akademik dan sikap siswa dapat dicapai melalui kebiasaan bekerjasama dalam pembelajaran di kelas.

Pendekatan think pair share adalah tipe model kooperatif yang berorientasi pada kerja sama dengan tujuan meningkatkan kemampuan berkomunikasi. Melalui pendekatan ini, diharapkan siswa akan mengalami peningkatan dalam berbicara, berdiskusi, bertanya dan menganalisis masalah-masalah social secara bersama-sama.

Atas dasar inilah yang memicu penulis untuk melakukan riset tentang implementasi pembelajaran kooperatif think pair share guna meningkatkan kualitas pembelajatan sosiologi.

\section{METODE}

Penelitian tindakan kelas menjadi metode dalam penelitian ini dengan maksud untuk meningkatkan kualitas tindakan di dalam situasi social (Elliot dalam Sulipan, 2008). Penelitian ini memiliki 2 siklus, dan setiap siklunya terdapat empat tahapan (planning, tindakan, observasi, dan refleksi), yang dilaksanakan selama 4 pertemuan disetiap siklusnya.

Adapun subjek dalam penelitian ini adalah siswa kelas X pada SMA Negeri 1 Lappariaja Kabupaten Bone. Dilaksanakan selama 3 bulan dengan jumlah siswa 39 orang (19 laki-laki dan 20 perempuan.

\section{HASIL DAN PEMBAHASAN}

\section{Analisis Kuatitatif}

Penjelasan hasil siklus I
Hasil siklus I diperoleh melalui ulangan harian setelah penyejian materi. Hasil analisis deksripsi skor perelehan dapat diamati pada table berikut:

Tabel 1

Statistik skor hasil tes siswa (Siklus I)

\begin{tabular}{|l|c|}
\hline Statistik & Nilai Statistik \\
\hline Objek & 39 \\
\hline Skor Ideal & 100 \\
\hline Skor Rata-rata & 65 \\
\hline Skor Tertinggi & 85 \\
\hline Skor Terendah & 45 \\
\hline Rentang Skor & 40 \\
\hline Standar deviasi & 10 \\
\hline
\end{tabular}

Setelah hasil tes siswa dimasukkan dalam 5 kategori, selanjutnya diperoleh distribusi persentasi dan frekuensi sebagai mberikut:

\section{Tabel 2}

Distribusi Frekuensi dan persentasi Skor tes (Siklus I)

\begin{tabular}{|l|l|l|c|}
\hline In. Skor & Kategori & Frek & Persentase \\
\hline $0-36$ & $\begin{array}{l}\text { Sangat } \\
\text { Rendah }\end{array}$ & 0 & $0 \%$ \\
\hline $37-56$ & Rendah & 8 & $20,5 \%$ \\
\hline $57-66$ & Sedang & 18 & $46,2 \%$ \\
\hline $67-89$ & Tinggi & 13 & $33,3 \%$ \\
\hline $90-100$ & $\begin{array}{l}\text { Sangat } \\
\text { Tinggi }\end{array}$ & 0 & 0 \\
\hline \multicolumn{2}{|c|}{ Jumlah } & 39 & $100 \%$ \\
\hline
\end{tabular}

Tabel di atas memperlihatkan jika tidak ada siswa yang berada dalam kategori sangat rendah, namun 8 atau 20,5\% siswa berada pada kategori rendah, 19 atau 46,2\% kategori sedang, 13 atau 33,3\% kategori tinggi, kemudian tidak ada siswa yang ada memiliki kategori sangat tinggi.

\section{Penjelasan hasil tes siklus II}


Berikut ini adalah hasil analisis skor hasil belajar setelah diimplementasikan metode kooperatif think pair share di dalam pembelajaran.

Tabel 3

Statistik hasil tes siswa (Siklus II)

\begin{tabular}{|l|c|}
\hline Statistik & Nilai Statistik \\
\hline Objek & 39 \\
\hline Skor Ideal & 100 \\
\hline Skor Rata-rata & 79 \\
\hline Skor Tertinggi & 95 \\
\hline Skor Terendah & 63 \\
\hline Rentang Skor & 32 \\
\hline Standar deviasi & 9 \\
\hline
\end{tabular}

Selanjutnya nilai hasil tes siswa dikelompokkan dalam 5 kategori yang dapat dilihat pada table berikut:

Tabel 4

Distribusi frekuensi dan persentasi nilai hasil tes siswa (Siklus II)

\begin{tabular}{|l|l|l|l|}
\hline Int. Skor & Kategori & Frek. & Persentasi \\
\hline $0-36$ & $\begin{array}{l}\text { Sangat } \\
\text { Rendah }\end{array}$ & 0 & $0 \%$ \\
\hline $37-56$ & Rendah & 0 & $0 \%$ \\
\hline $57-66$ & Sedang & 2 & $5,1 \%$ \\
\hline $67-89$ & Tinggi & 30 & $76,9 \%$ \\
\hline $90-100$ & $\begin{array}{l}\text { Sangat } \\
\text { Tinggi }\end{array}$ & 7 & 17,9 \\
\hline Jumlah & & $\mathbf{3 9}$ & $\mathbf{1 0 0 \%}$ \\
\hline
\end{tabular}

Tabel di atas menunjukkan jika tidak ada siswa yang berada pada kategori sangat rendah, dan rendah. Namun 2 atau 5,1\% pada kategori sedang, 30 atau 76,9\% pada kategori tinggi dan 7 atau $12,5 \%$ siswa berada pada level atau kategori sangat tinggi.

\section{Analisis kualitatif}

Berdasarkan hasil penelitian pada siklus I dan II, maka dapat dilihat perubahan keaktifan dan perubahan sikap siswa sebagai berikut:
Table 5

Keaktifan siswa (siklus I dan II)

\begin{tabular}{|c|c|c|c|c|}
\hline \multirow{2}{*}{$\begin{array}{l}\text { Komponen yang } \\
\text { Diamati }\end{array}$} & \multicolumn{4}{|c|}{ Siklus I } \\
\hline & $\bar{I}$ & II & III & $\%$ \\
\hline $\begin{array}{l}\text { Banyaknya siswa } \\
\text { yang hadir pada saat } \\
\text { proses } \\
\text { pembelajaran } \\
\text { berlangsung. }\end{array}$ & 38 & 38 & 37 & 96,6 \\
\hline $\begin{array}{l}\text { Siswa yang } \\
\text { memperhatikan } \\
\text { penjelasan guru. }\end{array}$ & 20 & 32 & 30 & 70,1 \\
\hline $\begin{array}{l}\text { Siswa yang } \\
\text { melakukan kegiatan } \\
\text { lain pada saat } \\
\text { pembahasan materi } \\
\text { pembelajaran. }\end{array}$ & 11 & 14 & 7 & 27,4 \\
\hline $\begin{array}{l}\text { Siswa yang aktif } \\
\text { dalam proses } \\
\text { pembelajaran. }\end{array}$ & 20 & 25 & 27 & 61,5 \\
\hline $\begin{array}{l}\text { Siswa } r \text { yang } \\
\text { bertanya mengenai } \\
\text { materi yang belum } \\
\text { dimengerti }\end{array}$ & 8 & 12 & 13 & 28,2 \\
\hline $\begin{array}{ll}\text { Siswa yang aktif } \\
\text { menjawab } \\
\text { pertanyaan } \\
\text { guru }\end{array}$ & 13 & 17 & 10 & 34,2 \\
\hline $\begin{array}{l}\text { Siswa yang aktif } \\
\text { dalam mengerjakan } \\
\text { LKS }\end{array}$ & - & - & 33 & 84,7 \\
\hline $\begin{array}{l}\text { Siswa yang } \\
\text { menyelesaikan } \\
\text { tugas dan PR }\end{array}$ & - & 34 & 30 & 82,1 \\
\hline $\begin{array}{ll}\text { Siswa yang } & \text { aktif } \\
\text { dalam } & \text { kerja } \\
\text { kelompok } & \end{array}$ & - & 34 & - & 87,2 \\
\hline
\end{tabular}




\begin{tabular}{|c|c|c|c|c|}
\hline \multirow{2}{*}{$\begin{array}{l}\text { Komponen } \\
\text { yang Diamati }\end{array}$} & \multicolumn{4}{|c|}{ Siklus II } \\
\hline & I & II & III & $\%$ \\
\hline $\begin{array}{l}\text { Banyaknya siswa } \\
\text { yang hadir pada } \\
\text { saat proses } \\
\text { pembelajaran } \\
\text { berlangsung. }\end{array}$ & 38 & 38 & 39 & 98,3 \\
\hline $\begin{array}{l}\text { Siswa yang } \\
\text { memperhatikan } \\
\text { penjelasan guru. }\end{array}$ & 32 & 35 & 36 & 87,2 \\
\hline $\begin{array}{l}\text { Siswa yang } \\
\text { melakukan } \\
\text { kegiatan lain pada } \\
\text { saat pembahasan } \\
\text { materi } \\
\text { pembelajaran. }\end{array}$ & 5 & 7 & 4 & 13,7 \\
\hline $\begin{array}{l}\text { Siswa yang aktif } \\
\text { dalam } \\
\text { pembelajaran. }\end{array}$ & 24 & 33 & 36 & 79,5 \\
\hline $\begin{array}{l}\text { Siswa yang aktif } \\
\text { dalam proses } \\
\text { pembelajaran. }\end{array}$ & 24 & 33 & 36 & 79,5 \\
\hline $\begin{array}{l}\text { Siswa yang } \\
\text { bertanya mengenai } \\
\text { materi yang belum } \\
\text { dimengerti }\end{array}$ & 10 & 4 & 5 & 16,2 \\
\hline $\begin{array}{l}\text { Siswa yang aktif } \\
\text { menjawab } \\
\text { pertanyaan } \\
\text { guru }\end{array}$ & 21 & 20 & 22 & 53,8 \\
\hline $\begin{array}{l}\text { Siswa yang aktif } \\
\text { dalam } \\
\text { mengerjakan LKS }\end{array}$ & - & - & 37 & 94,9 \\
\hline $\begin{array}{l}\text { Siswa yang } \\
\text { menyelesaikan } \\
\text { tugas dan PR }\end{array}$ & - & 35 & 38 & 93,6 \\
\hline $\begin{array}{ll}\text { Siswa yang aktif } \\
\text { dalam } & \text { kerja } \\
\text { kelompok } & \end{array}$ & - & 37 & - & 94,9 \\
\hline
\end{tabular}

Berdasarkan table 5 di atas, bisa dilihat bahwa sekitar 96,6 \% siswa hadir pada saat proses pembelajaran. $70,1 \quad \%$ siswa memperhatikan penjelasan guru. 27, 4\% siswa melakukan kegiatan lain pada saat proses pembelajaran berlansung. $61,5 \%$ siswa aktif dalam proses pembelajaran. $28,2 \%$ siswwa bertanya mengenai materi yang belum dimengerti. $34,2 \%$ siswa aktif menjawab pertanyaan yang disampaikan oleh guru. $84,7 \%$ siswa aktif mengerjakan lembar kerja siswa. 82,1 $\%$ siswa yang menyelesaikan PR, dan yang aktif dalam kerja kelompok terdiri dari 87,2\%.

Kemudian pada siklus II terdapat 98,3\% siswa yang hadir pada saat proses pembelajaran. $87,2 \%$ siswa yang perhatikan penjelasan guru pada saat pembelajaran. $13,7 \%$ siswa yang melakukan kegiatan lain pada saat proses pembelajaran. $79,5 \%$ aktif dalam proses pembelajaran. $16,2 \%$ aktif bertanya mengenai materi yang belum dipahami. 53,8\% siswa aktif dan antusias menjawab pertanyaan yang ditanyakan oleh guru. 94,9\% siswa menyelesaikan tugas dan pekerjaan rumah dan 94,9 siswa yang aktif dalam kerja kelompok.

\section{Analisis refleksi pelaksanaan tindakan dalam proses pembelajaran sosiologi}

\section{Pendapat siswa mengenai pelajaran sosiologi}

Secara umum, siswa sangat menyukai pelajaran sosiologi. Hal tersebut dapat dilihat dari populasi siswa IPS lebih banyak disbanding dengan jurusan lain. Selanjutnya, dalam jurusan IPS, kebanyakan pelajaran sosiologi menjadi peminatan mereka.

Diantara mereka berpandangan bahwa pelajaran sosiologi sangatlah penting untuk dipahami tanpa terkecuali jurusan IPS, karena dianggap sosiologi sangat berguna dalam kehidupan bermasyarakat maupun dalam bidangbidang tertentu.

Selanjutnya, hasil penyebaran angket ke 39 siswa sebagai objek penelitian maka pada umunya mereka berpendapat jika pelajaran sosiologi itu rumit tetapi dengan adanya metode yang menyenangkan maka mereka kembali 
bersemangat untuk belajar sosiologi meskipun dianggap sulit.

\section{Respon siswa terhadap implementasi model pembelajaraan kooperatif think pair share}

Implementasi model pembelajaran kooperatif think pair share mendapat respon positif dari para siswa. Hal tesebut dibuktikan dengan hasil penyebaran angket ke 39 siswa yang menyatakan mereka sangat percaya diri untuk belajar lebih aktif melalui metode pembelajaran yang diterapkan dengan penekanan pada kerjasama antar kelompok. Kemudian ada 36 siswa yang menyatakan semakin antusias dan berminat kembali belajar sosiologi setelah diterapkan model pembelajartan tersebut. Selanjutnya terdapat 39 siswa yang mengatakan sepakat bilamana model pembelajaran think pair share dapat meningkatkan hali belajar mereka.

Berdasarkan hasil yang telah dipaparkan, maka implementasi model pembelajaran think phair share mampu menimbulkan berbagai perubahan pada siswa sebagai berikut:

1. Keaktifan siswa pada proses pembelajaran mengalami peningkatan dari $96,6 \%$ menjadi $98,3 \%$.

2. Perhatian siswa terhadap penjelasan guru mengalami peningkatan dari $70,1 \%$ menjadi $87,2 \%$.

3. Kegiatan lain yang dilakukan siswa pada saat proses pembelajaran berlansung mengalami penurunan dari $27,4 \%$ menjadi $13,7 \%$.

4. Keaktifan dalam pembelajaran meningkat dari $61,5 \%$ menjadi $79,5 \%$.

5. Keaktifan siswa dalam bertanya mengenai materi yang disampaikan mengalami penurunan dari 28,2 \% menjadi $16,2 \%$.

6. Keaktifan siswa dalam menjawab pertanyaan yang diberikan meningkat dari $34,2 \%$ menjadi $53,8 \%$.
7. Keaktifan siswa dalam menyelesaikan LKS meningkat dari $84,7 \%$ menjadi 94,9\%.

8. Penyelesaian tugas-tugas dan $\mathrm{PR}$ oleh siswa mengalami peningkatan dari $82,1 \%$ menjadi $93,6 \%$.

9. Keaktifan siswa dalam kerja kelompok mengalami peningkatan dari 87,2\% menjadi $94,9 \%$

Sesuai dengan indikator keberhasilan, hasil belajar bisa dikatakan mengalami peningkatan bilamana skor rata-rata hasil belajar siswa mengalami peningkatan. Siswa bisa dikatakan tuntas belajar jika memperoleh skor minimal 67 dari skor ideal dan tuntas secara klasikal jika mencapai minimal 90\% dari jumlah siswa dalam kelas yang dinyatakan tuntas belajar.

Berdasarkan data yang diperoleh, hasil belajar pada siklus pertama adalah 65 dan berada pada kategori sedang. Selanjutnya pada siklus kedua adalah 79 dan berada pada kategori tinggi. Berdasarkan data tesebut juga telah mencapai standar KKM yang sudah ditentukan yaitu 67 . Hal tesebut memberikan gambaran bahwa terjadi peningkatan skor rata-rata hasil belajar sebesar 14. Hasil penelitian juga menunjukkan ada 37 siswa $(94,9 \%)$ yang mencapai ketuntasan belajar dari 39 siswa yang dijadikan objek penelitian. Oleh karena itu, implementasi model pembelajaran ini dapat meningkatkan hasil belajar.

\section{PENUTUP}

\section{Simpulan}

Melalui implementasi model pembelajaran think pair share dapat meningkatkan hasil belajar siswa. Peningkatan tesebut dapat dilihat pada hasil belajar siswa yang semula rata-rata 65 atau kategori sedang pada siklus I, meningkat pada siklus II menjadi rata-rata 79 dengan kategori tinggi serta mampu mencapai ketuntasan nilai minimal yaitu 67 . 


\section{Saran}

1. Guru harus memberikan kesempatan yang banyak kepada siswa untuk lebih kreatif dan inovatif dalam proses pembelajaran.

2. Diharapkan guru dalam pembelajaran menggunakan model dan strategi yang menyenangkan bagi siswa dan sesuai dengan materi yang diajarkan.

\section{DAFTAR PUSTAKA}

Daroeso, Bambang. 1986. Dasar dan konsep Pendidikan moral peancasila. Semarang: Aneka

Miarso, Yusuf Hadi. 2004. Menyemai benih teknologi Pendidikan. Jakarta: Pranada Media

Oemar, Hamalik. 2003. Metode Belajar dan Kesulitan-kesulitan Belajar. Bandung: Remaja Karya

Suparno, P. 2007. Metodologi Pembelajaran Konstruktivistik dan Menyenangkan. Yogyakarta: Sanata Dharma

Rusmono. 2012. Strategi Pembelajaran dengan Problem Based Learning itu perlu. Bogor: Ghalia Indonesia

West, M. 2002. Effective Teamwork Kerja Sama Kelompok yang Efektif. Yogyakarta: Kanisius 